\title{
High-intensity interval training in the prehabilitation of cancer patients-a systematic review and meta-analysis
}

\author{
Stefano Palma ${ }^{1} \cdot$ Timothy Hasenoehrl $^{1} \cdot$ Galateja Jordakieva $^{1} \cdot$ Dariga Ramazanova $^{2} \cdot$ Richard Crevenna $^{1}$ (i)
}

Received: 17 May 2020 / Accepted: 15 October 2020 / Published online: 26 October 2020

(C) The Author(s) 2020

\begin{abstract}
Purpose To evaluate the impact of high-intensity interval training (HIIT) on health-related outcome parameters in the prehabilitation of patients diagnosed with cancer.

Methods A systematic review and meta-analysis of comparative studies on HIIT in cancer prehabilitation conducted by screening standard databases from their inception to March 30, 2020. Outcomes of interest included cardiorespiratory fitness, feasibility, safety, clinical, and patient-reported outcomes.

Results Of the 855 identified studies, 8 articles met the inclusion criteria ( 7 randomized, 1 non-randomized controlled trial) with a total of 896 patients. The study protocols were heterogeneous, but the methodological quality ranged from good to high according to PEDro scale. Meta-analysis revealed a significant improvement of peak oxygen consumption $\left(\mathrm{VO}_{2}\right.$ peak $)$ achieved with HIIT compared to usual care. Furthermore, HIIT was feasible and safe, showing low risk of adverse events and positive effects on health-related outcomes in prehabilitative settings.

Conclusion In the phase of prehabilitation, HIIT has potential health benefits in patients diagnosed with cancer and is feasible and safe to perform. Nonetheless, larger randomized controlled trials focusing on long-term effects (such as cancer recurrence or survival rates) are missing, to underline the potential relevance of HIIT for cancer patients.
\end{abstract}

Keywords Prehabilitation $\cdot$ Preoperative care $\cdot$ Cancer $\cdot$ High-intensity interval training $\cdot$ Meta-analysis $\cdot$ Systematic review . Exercise

\section{Introduction}

Cancer is estimated to have caused more than 9.8 million deaths in 2018 and is the second leading cause of death globally after cardiovascular diseases [1]. However, depending on tumor entity and stage, many highly effective individualized therapy modalities exist, leading to an increasing number of cancer survivors who require specific long-term management

Supplementary Information The online version contains supplementary material available at https://doi.org/10.1007/s00520-02005834-x.

Richard Crevenna

richard.crevenna@meduniwien.ac.at

1 Department of Physical Medicine, Rehabilitation and Occupational Medicine, Medical University of Vienna, Waehringer Guertel 18-20, A-1090 Vienna, Austria

2 Center for Medical Statistics, Informatics and Intelligent Systems (CeMSIIS), Medical University of Vienna, Vienna, Austria
[2]. A substantial proportion of these patients suffer from typical adverse effects of the disease itself and its treatments (e.g., fatigue, deconditioning), causing disruption in all aspects of quality of life (QoL). Regular strength and endurance training potentially mitigates tumor- and treatment-related adverse effects and consequently have beneficial effects on QoL, physical fitness, and cancer-related fatigue [3-5]. Furthermore, exercise has been demonstrated to reduce all-cause, cancer-related, and cardiovascular disease mortality [6, 7]. Therefore, recent guidelines from the American College of Sports Medicine recommend exercise for all suitable patients with cancer, regardless of cancer stage [8]. Moreover, pooled data from European and US cohorts including more than 1.44 million participants with no cancer diagnosis at baseline indicated that higher leisure time activity levels ( $\geq 6 \mathrm{METs}$ ) resulted in a $\geq 20 \%$ risk reduction for developing esophageal, liver, lung, kidney, gastric cardia, and endometrium carcinoma compared with low activity levels, indicating that exercise intensity might also positively influence health-related outcomes [9]. 
Prehabilitation in oncology describes the systematic process of improving the physical, psychosocial, and nutritional status of patients between diagnosis and posttreatment recovery to increase the ability to cope with the upcoming physiological stress of the specific cancer-related therapy [10]. Presurgical training interventions in cancer patients have been the most frequently cited programs for prehabilitation, showing efficacy in reducing postoperative stress and complications, duration of hospital stay, and improving clinical outcomes by optimizing cardiopulmonary reserve prior to surgery [11-13]. Neoadjuvant therapy strategies have been shown to improve resectability of previously inoperable cancers by reducing the complexity of operations, e.g., by successfully diminishing tumor tissue [14]. However, prehabilitation programs are also targeting non-surgical cancer patients receiving pharmacological treatment only, e.g., as chemotherapy and/or radiotherapy [15-17]. In this context, a recent meta-analysis on 3257 patients with cancer indicated that moderate aerobic exercise performed at $70-80 \%$ of maximum heart rate not only was feasible and safe but also showed beneficial effects in QoL and physical functioning and maintained or at least improved fitness during concomitant chemotherapy [18]. Although not without bearing a considerably risk of bias, pooled data from another recent metaanalysis revealed that prehabilitation significantly improved mood, physical well-being, and immune function for prostate cancer patients and improved fatigue and psychological outcomes with a trend indicating better QoL among breast cancer patients [19].

In both mono- (aerobic and/or resistance exercise alone) and multimodal prehabilitative settings (exercise in combination with smoking cessation, nutritional, and psychological support), endurance exercise plays a fundamental role in the management and care of cancer patients, and increasing evidence suggests that aerobic high-intensity interval training (HIIT) may be superior to established moderate continuous intensity interventions [20]. HIIT is defined as a discontinuous mode of endurance exercise characterized by relatively short bouts of high-intensity workloads interspersed by periods of rest or low-intensity activity during recovery [21]. It was demonstrated that HIIT is effective and a safe therapy option for improving cardiovascular fitness, which is measured by peak oxygen uptake $\left(\mathrm{VO}_{2 \text { peak }}\right)$, in cancer and non-cancer patients. $\mathrm{VO}_{2 \text { peak }}$ is strongly associated with all-cause, cancer-related, and cardiovascular disease mortality $[6,7]$. The rationale behind interval training programs is that the total accumulated time of vigorous exercise is higher than what could be achieved during a single bout of continuous exercise at the same intensity before getting exhausted; moreover, it results in more pronounced cardio-metabolic adaptions than moderate intensities [22]. This time-efficient and effective method might be particularly relevant when the period from diagnosis to surgery, and therefore, the timeframe for a potential training intervention is limited. Nevertheless, patients might benefit from cardiovascular improvements, e.g., lung cancer patients awaiting lung resection surgery [23, 24]. In this regard, $\mathrm{VO}_{2 \text { peak }}$ has emerged as the strongest independent predictor for surgical complications and survival rates in non-small cell lung cancer $[25,26]$. Adams and colleagues found that HIIT increased muscular function and significantly reduced dyspnea and fatigue symptoms in testicular cancer patients. In addition, an optimization of body composition (which goes hand in hand with a reduction of the cardiovascular risk profile by reducing body fat and increasing lean mass) as well as a reduction of arterial stiffness and thickness, microvascular inflammation and dyslipidemia have been reported in this context [27]. Additionally, studies indicated that HIIT improved not only QoL but also mood state [28], emotion, pain [29], and cognitive health [30] in different study populations.

In 2019, a meta-analysis focusing on treatment and aftercare in cancer survivors revealed that HIIT significantly increased cardiorespiratory fitness in cancer patients compared with usual care (UC) [31]. However, the study did not focus specifically on outcomes of HIIT in prehabilitation. Therefore, to underline its relevance in this field, this systematic review and meta-analysis aimed to evaluate the feasibility and safety of HIIT and its impact on cardiorespiratory fitness and patientreported outcomes compared with UC in cancer patients.

\section{Methods}

A comprehensive systematic search of the literature was conducted by two authors in line with the Preferred Reporting Items for Systematic Review and Meta-Analysis (PRISMA) guidelines [32]; the electronic databases CENTRAL, Medline/Pubmed, Embase, and CINAHL were searched. $\mathrm{VO}_{2 \text { peak }}$ and peak power output measured in Watts were the primary outcomes.

\section{Eligibility criteria}

\section{Inclusion criteria}

- Randomized and non-randomized controlled exercise intervention trials with at least one treatment arm being HIIT (regardless of combination with other exercise intervention like resistance training $[\mathrm{RT}]$ and/or moderate intensity continuous training [MICT])

- Control group receives UC

- Only studies with cancer patients in a prehabilitative context

- Reporting/availability of complete pre- and postinterventional $\mathrm{VO}_{2 \text { peak }}$ data 


\section{Exclusion criteria}

- Any non-interval exercise intervention trials

- Retrospective trials, case reports/case series, reviews, letters, editorials, commentary

- Language limitations (not in English or German)

- Animal studies

\section{Search strategy}

Databases were screened for accessible English languagerandomized and non-randomized controlled trials published up to March 2020. The following search terms related to cancer, exercise, and prehabilitation were used: "high intensity training" (all fields) OR "high intensity exercise" (all fields) OR "vigorous exercise" (all fields) OR "high intensity intermittent exercise" (all fields) OR "high intensity functional training" (all fields) OR "interval exercise training" (all fields) OR "interval training" (all fields) OR "high intensity interval training" (all fields) AND "prehabilitation" (all fields) OR "preoperative" (all fields) OR "supportive" (all fields) OR "surgery" (all fields).

\section{Study selection and data extraction}

Two reviewers (one medical doctor [SP] and one sport scientist [TH]) independently screened the titles and abstracts of the eligible studies. The full texts of the potentially qualified records were retrieved and screened, and relevant data were extracted. The study selection process is described in the PRISMA flow diagram (Fig. 1). In cases of insufficient data reporting, the authors of the original paper were contacted via email. If this was not possible, the study was excluded. Any discrepancies in the data extraction process between the two reviewers were resolved by discussion.

\section{Methodological quality assessment}

To evaluate the methodological quality and risk of bias of the included studies, two reviewers independently used the 10point PEDro scale, which is based on the Delphi list, developed by Verhagen and colleagues [33]. The PEDro scale allows a maximum of 10 points. As blinding of therapists and patients is de facto impossible to achieve in exercise intervention trials, PEDro scores of 7-8 were considered as high methodological quality. A cut-off of 5 points (equal to or greater than) on the PEDro scale indicates good quality, and a score equal to or less than 4 points indicates poor quality. Disagreements were resolved by discussion between the reviewers, or a third independent reviewer was consulted.

\section{Statistical analysis}

The primary endpoint of the meta-analysis was the average difference in $\mathrm{VO}_{2 \text { peak }}$ and peak power output between the two groups: HIIT vs. UC. The measurements were assessed before and after the training intervention. Some authors reported both, the means and their standard deviations. For studies that lacked this information, the mean differences were calculated with simple subtraction ("mean_end" - "mean_bsl"). The missing standard deviations at baseline and after training were back-calculated from the confidence intervals reported in the original studies (i.e., a two-sided confidence interval for a paired sample mean difference from a normal distribution with unknown variance). Some authors reported both the average difference between HIIT and UC and their confidence intervals and $p$ values. For studies that were lacking this information, mean differences were calculated with simple subtraction ("mean_diff" of HIIT -"mean_diff" of UC). The 95\% CI of the average difference for Bhatia et al. [23] was calculated under the assumption that the data were normally distributed (which is appropriate given the sample size). Other missing standard errors were estimated using the average correlation of two studies: Dunne et al. [34] and West et al. [35], because these studies used simple between-group comparisons, whereas other studies conducted more complex statistical analyses $[17,36]$, which do not allow for the calculation of the correlation based on the reported summary statistics. The statistical analyses were calculated using meta-analyses with a random intercept for each study. The models were fitted via restricted maximum-likelihood ("REML") estimation; test statistics and confidence intervals for the fixed effects were computed based on a $t$ distribution. All statistical analyses were performed using the Metafor package, R (version 3.6).

The presentation of intervention data was based on the FITT (frequency, intensity, time, and type) principle, which is an established framework for exercise prescriptions. The four components constitute the exercise quantity and dose necessary to improve health parameters equally to a pharmacologic intervention [37].

\section{Results}

\section{Literature search}

The combined database search yielded 855 results. After removing duplicates and screening according to inclusion criteria, eight articles fulfilled the eligibility criteria and were used for the qualitative and quantitative synthesis. The flowchart summarizes the screening process (Fig. 1). 


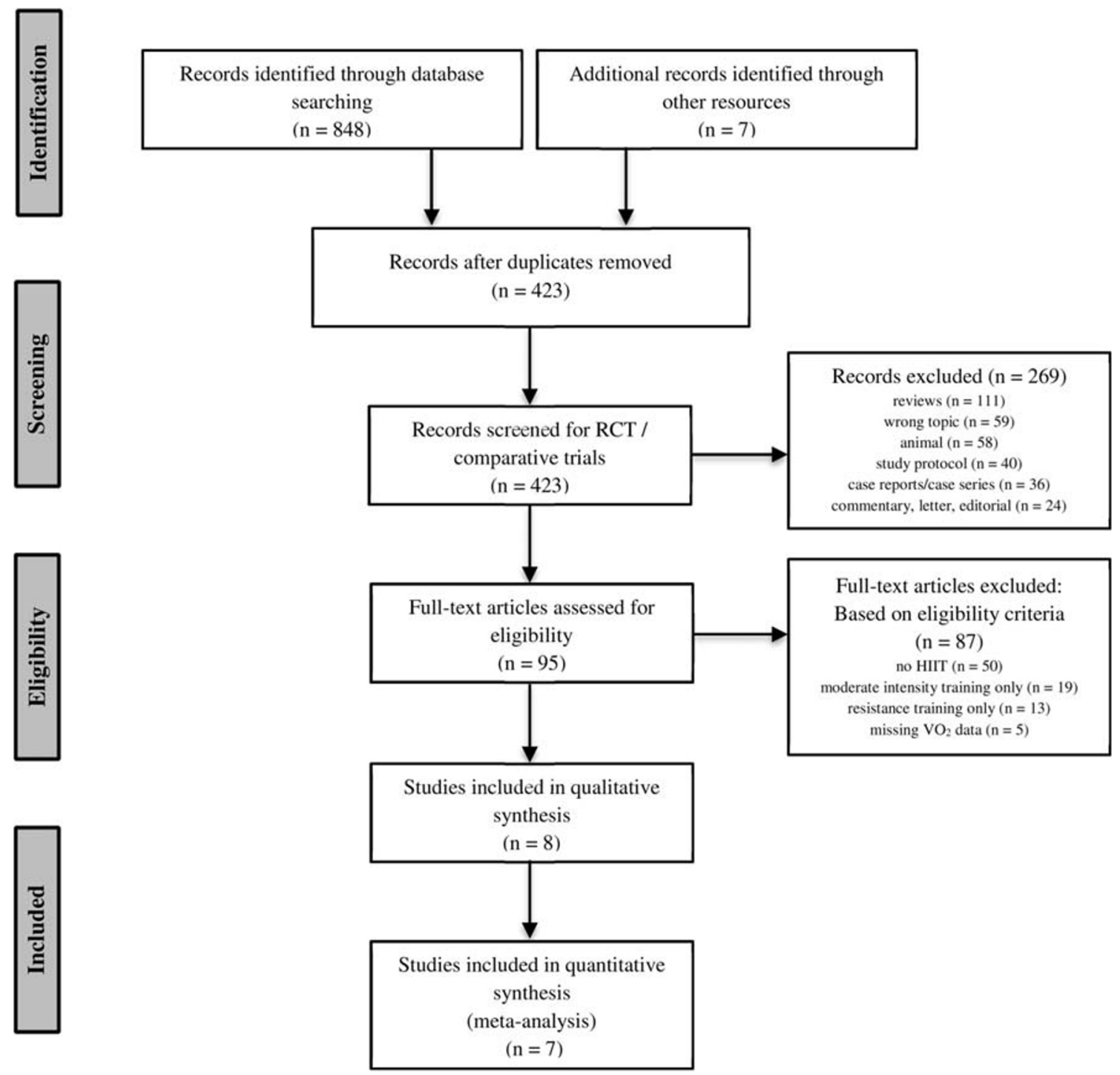

Fig. 1 Flow chart of the screening process

\section{Overall study characteristics}

The overview and characteristics of the included studies are presented in Table 1. Overall, seven RCTs [15-17, 23, 24, 34, 36 ] and one non-randomized controlled trial [35] with a total of 896 patients with a mean age of $61( \pm 8)$ years were identified. Seven of the eight studies used a two-arm design (HIIT vs. UC) [16, 17, 23, 24, 34-36], whereas one study had a mixed three-arm design comparing HIIT/RT vs. HIIT/MICT vs. UC [15]. No studies were identified that compared HIIT vs. MICT in a prehabilitative setting. Three studies reported on non-small cell lung carcinoma $[17,23,24]$, two on colorectal cancer [34, 35], one on breast cancer [15], one on bladder cancer [36], and one on different cancer entities [16]. Five studies were conducted on patients awaiting cancer surgery [23, 24, 34-36], two on patients during concomitant chemotherapy $[15,16]$, and one on patients scheduled for radiotherapy [17].

Concerning eligibility criteria, five studies included patients with a diseases stage of III or less (= without peripheral metastases) [15, 16, 23, 24, 35], two studies explicitly included more advanced stages of disease [17, 34], whereas one study did not report any staging [36]. To determine pre-treatment performance status of cancer patients, three studies limited the inclusion criteria for patients to a WHO performance status $<1$ [16, 17] and $<2$ [35], while the other studies did not mention any criteria.

One of the eight studies assessed exercise history and consequently excluded patients who performed more than 150 min of moderate intensity per week [36]. Overall physical activity levels were assessed in two studies with the 
Table 1 Main characteristics of the included studies

\begin{tabular}{|c|c|c|c|c|c|c|c|}
\hline Reference & Design & $\begin{array}{l}\text { Patients } \\
\text { at } \\
\text { baseline }\end{array}$ & Age & $\begin{array}{l}\text { Disease/ } \\
\text { prehabilitation } \\
\text { phase }\end{array}$ & $\begin{array}{l}\text { Inclusion/exclusion } \\
\text { criteria }\end{array}$ & $\begin{array}{l}\text { Main outcome } \\
\text { parameters/ } \\
\text { questionnaires }\end{array}$ & Conclusion \\
\hline $\begin{array}{c}\text { Bhatia C, } \\
2019 \\
{[23]}\end{array}$ & $\begin{array}{l}\text { Randomized } \\
\text { controlled trial }\end{array}$ & 151 & $\begin{array}{l}\text { HIIT: } 64(13) \\
\text { UC: } 64 \text { (10) }\end{array}$ & $\begin{array}{l}\text { Non-small cell } \\
\text { lung } \\
\text { carcinoma, } \\
\text { stage; } \\
\text { presurgical }\end{array}$ & $\begin{array}{l}\text { Incl.: NSCLC, stage IIIA } \\
\text { or less } \\
\text { Excl.: contraindications for } \\
\text { cardiopulmonary } \\
\text { exercise testing (e.g., } \\
\text { uncontrolled cardiac } \\
\text { disease, severe } \\
\text { pulmonary } \\
\text { hypertension, } \\
\text { uncontrolled asthma), } \\
\text { limitations to adhere to } \\
\text { prehabilitation (e.g., } \\
\text { cycling difficulties) }\end{array}$ & $\begin{array}{l}\text { Cardiorespiratory } \\
\text { fitness }\left(\mathrm{VO}_{2 \text { peak }}\right) \\
6 \mathrm{MWT}, \text { oxygen } \\
\text { saturation, leg } \\
\text { fatigue, and dyspnea } \\
\text { (BORG scale) }\end{array}$ & $\begin{array}{l}\text { Short-term HIIT was } \\
\text { feasible and safe in } \\
\text { preoperative setting and } \\
\text { increased } \\
\text { cardiorespiratory fitness }\end{array}$ \\
\hline $\begin{array}{l}\text { Egegaard } \\
\text { T, } 2019 \\
{[17]}\end{array}$ & $\begin{array}{l}\text { Randomized } \\
\text { controlled trial }\end{array}$ & 13 & $\begin{array}{l}\text { HIIT: } 64 \\
\quad(5.8) \\
\text { UC: } 65(4.7)\end{array}$ & $\begin{array}{l}\text { Non-small cell } \\
\text { lung } \\
\text { carcinoma; } \\
\text { during } \\
\text { concomitant } \\
\text { radiotherapy }\end{array}$ & $\begin{array}{l}\text { Incl.: NSCLC, age } \\
\geq 18 \text { years, stage } \\
\text { IIIA-IV, WHO } \\
\text { performance status 0-1 } \\
\text { with concomitant che- } \\
\text { moradiotherapy } \\
\text { Excl.: any symptoms or } \\
\text { circumstances that } \\
\text { advise against physical } \\
\text { activity; symptomatic } \\
\text { heart disease (e.g., } \\
\text { arrhythmia or } \\
\text { myocardial infarction } \\
\text { within the last } \\
3 \text { months) }\end{array}$ & $\begin{array}{l}\text { Cardiorespiratory } \\
\text { fitness }\left(\mathrm{VO}_{2 \text { peak, }}\right. \\
\left.\mathrm{WR}_{\text {peak }}\right) \text {, activity } \\
\text { data (steps), } \\
\text { pulmonary function, } \\
\text { HADS, FACT-L, } \\
\text { 6MWT, IPAQ-L }\end{array}$ & $\begin{array}{l}\text { High intensity was feasible, } \\
\text { safe, and well tolerated } \\
\text { during concomitant } \\
\text { chemoradiotherapy; no } \\
\text { significant differences } \\
\text { within or between } \\
\text { groups in any secondary } \\
\text { outcome }\end{array}$ \\
\hline $\begin{array}{l}\text { Mijwel S, } \\
2019 \\
{[15]}\end{array}$ & $\begin{array}{l}\text { Randomized } \\
\text { controlled trial }\end{array}$ & 175 & $\begin{array}{l}\text { HIIT/RT: } \\
\quad 52.7 \\
(10.3) \\
\text { HIIT/MICT: } \\
54.4 \\
(10.3) \\
\text { UC: } 52.6 \\
(10.2)\end{array}$ & $\begin{array}{l}\text { Breast cancer; } \\
\text { during } \\
\text { concomitant } \\
\text { chemothera- } \\
\text { py }\end{array}$ & $\begin{array}{l}\text { Incl.: women with breast } \\
\text { cancer, aged } \\
\text { 18-70 years, stage } \\
\text { I-IIIa, planned to } \\
\text { receive adjuvant } \\
\text { chemotherapy } \\
\text { Excl.: advanced disease, } \\
\text { heart or lung disease, } \\
\text { cognitive dysfunction }\end{array}$ & $\begin{array}{l}\text { Cardiorespiratory } \\
\text { fitness }\left(\mathrm{VO}_{2 \text { peak }}\right), \\
\text { PFS, EORTC-QLQ } \\
\text { C30, MSAS, muscle } \\
\text { strength, return to } \\
\text { work }\end{array}$ & $\begin{array}{l}\text { Intervention groups } \\
\text { showed beneficial } \\
\text { effects on cancer-related } \\
\text { fatigue, symptoms, and } \\
\text { muscle strength, } \\
12 \text { months following } \\
\text { the commencement of } \\
\text { chemotherapy }\end{array}$ \\
\hline $\begin{array}{l}\text { Banerjee S, } \\
2017 \\
{[36]}\end{array}$ & $\begin{array}{l}\text { Randomized } \\
\text { controlled trial }\end{array}$ & 60 & $\begin{array}{l}\text { HIIT: } 71.6 \\
\quad(6.8) \\
\text { UC: } 72.5 \\
(8.4)\end{array}$ & $\begin{array}{c}\text { Bladder cancer; } \\
\text { presurgical }\end{array}$ & $\begin{array}{l}\text { Incl.: bladder cancer } \\
\text { patients listed for radical } \\
\text { cystectomy ( } \pm \\
\text { neoadjuvant } \\
\text { chemotherapy) } \\
\text { Excl.: patients with urinary } \\
\text { diversion for benign } \\
\text { disease, patients } \\
\text { meeting current physical } \\
\text { activity guidelines } \\
\text { ( } \geq 150 \text { min of moderate } \\
\text { intensity per week) }\end{array}$ & $\begin{array}{l}\text { Cardiorespiratory } \\
\text { fitness }\left(\mathrm{VO}_{2 \text { peak }}, \mathrm{AT},\right. \\
\left.\mathrm{WR}_{\text {peak }}\right), \text { feasibility, } \\
\text { Clavien Dindo } \\
\text { classification, LOS }\end{array}$ & $\begin{array}{l}\text { HIIT was feasible and well } \\
\text { tolerated and improved } \\
\text { cardiopulmonary fitness }\end{array}$ \\
\hline $\begin{array}{l}\text { Karenovics } \\
\qquad \mathrm{W}, 2017 \\
{[24]}\end{array}$ & $\begin{array}{l}\text { Randomized } \\
\text { controlled trial }\end{array}$ & 151 & $\begin{array}{l}\text { HIIT: } 64(13) \\
\text { UC: } 64 \text { (10) }\end{array}$ & $\begin{array}{l}\text { Non-small cell } \\
\text { lung } \\
\text { carcinoma; } \\
\text { presurgical }\end{array}$ & $\begin{array}{l}\text { Incl.: proven or suspected } \\
\text { NSCLC, stage IIIA or } \\
\text { less, awaiting lung } \\
\text { resection surgery } \\
\text { Excl.: any contraindication } \\
\text { for CPET (e.g., } \\
\text { uncontrolled cardiac } \\
\text { disease, severe } \\
\text { pulmonary } \\
\text { hypertension, } \\
\text { limitations impeding } \\
\text { cycling); inability to } \\
\text { adhere to a rehabilitation } \\
\text { program }\end{array}$ & $\begin{array}{l}\text { cardiorespiratory fitness } \\
\left(\mathrm{VO}_{2 \text { peak }}, \mathrm{WR}_{\text {peak }}\right) \\
\text { pulmonary function } \\
\text { test, survival (1y FU) }\end{array}$ & $\begin{array}{l}\text { Preoperative rehabilitation } \\
\text { with HIIT does not } \\
\text { improve pulmonary } \\
\text { function and aerobic } \\
\text { capacity } 1 \text { year after } \\
\text { lung cancer resection, } \\
\text { survival after } 1 \text { year was } \\
\text { equal, postop } \\
\text { pulmonary } \\
\text { complications less in } \\
\text { HIIT }\end{array}$ \\
\hline
\end{tabular}


Table 1 (continued)

\begin{tabular}{|c|c|c|c|c|c|c|c|}
\hline Reference & Design & $\begin{array}{l}\text { Patients } \\
\text { at } \\
\text { baseline }\end{array}$ & Age & $\begin{array}{l}\text { Disease/ } \\
\text { prehabilitation } \\
\text { phase }\end{array}$ & $\begin{array}{l}\text { Inclusion/exclusion } \\
\text { criteria }\end{array}$ & $\begin{array}{l}\text { Main outcome } \\
\text { parameters/ } \\
\text { questionnaires }\end{array}$ & Conclusion \\
\hline $\begin{array}{l}\text { Dunne DFJ, } \\
2016 \\
{[34]}\end{array}$ & $\begin{array}{l}\text { Randomized } \\
\text { controlled trial }\end{array}$ & 38 & $\begin{array}{l}\text { HIIT: } 61 \\
\quad(56-68) \\
\text { UC: } 62 \\
\quad(53-72)\end{array}$ & $\begin{array}{l}\text { Colorectal liver } \\
\text { metastasis } \\
\text { patients, } \\
\text { presurgical }\end{array}$ & $\begin{array}{l}\text { Incl.: resectable colorectal } \\
\text { liver metastasis, age } \\
\geq 18 \text { years, partake in } \\
\text { cycle-based exercise, } \\
\text { complete the exercise } \\
\text { program before the pro- } \\
\text { posed surgery date, at } \\
\text { least } 4 \text { weeks of } \\
\text { prehabilitation } \\
\text { Excl.: pre-existing chronic } \\
\text { liver disease, recruit- } \\
\text { ment to the study must } \\
\text { not result in delayed } \\
\text { surgical care }\end{array}$ & $\begin{array}{l}\text { cardiorespiratory fitness } \\
\left(\mathrm{VO}_{2 \text { peak }}, \mathrm{AT},\right. \\
\left(\mathrm{WR}_{\text {peak }}\right), \mathrm{SF}-36\end{array}$ & $\begin{array}{l}\text { HIIT was feasible and safe, } \\
\text { the intervention reduced } \\
\text { fatigue, improved } \\
\text { vitality, aerobic } \\
\text { capacity, muscular } \\
\text { strength, physical and } \\
\text { functional activity, } \\
\text { emotional well-being, } \\
\text { but not quality of life }\end{array}$ \\
\hline $\begin{array}{l}\text { West MA, } \\
2015 \\
{[35]}\end{array}$ & $\begin{array}{l}\text { Non-randomized } \\
\text { controlled trial }\end{array}$ & 39 & $\begin{array}{l}\text { HIIT: } 64 \\
\quad(45-82) \\
\text { UC: } 72 \\
\quad(62-84)\end{array}$ & $\begin{array}{l}\text { Non-metastatic } \\
\text { locally } \\
\text { advanced } \\
\text { rectal cancer, } \\
\text { presurgical }\end{array}$ & $\begin{array}{l}\text { Incl.: locally advanced } \\
\text { resectable rectal cancer, } \\
\text { age } \geq 18 \text { years, stage } \\
\text { T2/N+, no distant } \\
\text { metastasis, WHO } \\
\text { performance status <2, } \\
\text { undergoing NACRT } \\
\text { Excl.: nonresectable } \\
\text { disease, inability to } \\
\text { perform CPET or } \\
\text { bicycle exercise, } \\
\text { patients who declined } \\
\text { surgery or NACRT, } \\
\text { patients who received } \\
\text { non-standard NACRT }\end{array}$ & $\begin{array}{l}\text { Cardiorespiratory } \\
\text { fitness }\left(\mathrm{VO}_{2 \text { peak }}, \mathrm{LT},\right. \\
\left.\mathrm{WR}_{\text {peak }}\right), \text { spirometry, } \\
\text { MRI staging }\end{array}$ & $\begin{array}{l}\text { Chemoradiotherapy before } \\
\text { rectal cancer surgery } \\
\text { reduced physical fitness; } \\
\text { however, a 6-week ex- } \\
\text { ercise intervention was } \\
\text { feasible and returns fit- } \\
\text { ness to baseline levels }\end{array}$ \\
\hline $\begin{array}{l}\text { Adamsen } \\
\quad \mathrm{L}, 2009 \\
{[16]}\end{array}$ & $\begin{array}{l}\text { Randomized } \\
\text { controlled trial }\end{array}$ & 269 & $\begin{array}{l}\text { HIIT: } 47.2 \\
\quad(10.7) \\
\text { UC: } 47.2 \\
(10.6)\end{array}$ & $\begin{array}{l}\text { Non-metastatic } \\
\text { cancer } \\
\text { patients } \\
\text { undergoing } \\
\text { chemothera- } \\
\text { py }\end{array}$ & $\begin{array}{l}\text { Incl.: a diagnosis of cancer, } \\
\text { aged } 18-65 \text { years, at } \\
\text { least one cycle of } \\
\text { chemotherapy for } \\
\text { advanced disease or as } \\
\text { adjuvant treatment, } \\
\text { WHO performance } \\
\text { status of } 0 \text { or } 1 \\
\text { Excl.: brain or bone } \\
\text { metastases, } \\
\text { thrombocytopenia } \\
(<50 \times 109 / 1), \\
\text { myocardial infarction } \\
\text { within the past } \\
3 \text { months, uncontrolled } \\
\text { hypertension (diastolic } \\
\text { pressure }>95 \text { mmHg) }\end{array}$ & $\begin{array}{l}\text { Cardiorespiratory } \\
\text { fitness }\left(\mathrm{VO}_{2 \text { peak }}\right), \\
\text { EORTC-QLQ C30, } \\
\text { Medical Outcomes, } \\
\text { SF-36, Leisure Time } \\
\text { Physical Activity } \\
\text { Quest., muscular } \\
\text { strength }\end{array}$ & $\begin{array}{l}\text { HIIT was feasible and safe, } \\
\text { the intervention reduced } \\
\text { fatigue, improved } \\
\text { vitality, aerobic } \\
\text { capacity, muscular } \\
\text { strength, physical and } \\
\text { functional activity, } \\
\text { emotional well-being, } \\
\text { but not quality of life }\end{array}$ \\
\hline
\end{tabular}

Incl inclusion, Excl exclusion, BL baseline, FU follow-up, AT anaerobic threshold, $L T$ lactate threshold, WRpeak work rate peak, EORTC-QLQ C30, European Organisation for Research and Treatment of Cancer/Core Quality of Life Questionnaire, LOS length of stay, PFS Piper Fatigue Scale, MSAS Memorial Symptom Assessment Scale, HADS Hospital Anxiety and Depression Scale, IPAQ-L International Physical Activity Questionnaire, NSCLC non-small cell lung carcinoma, $C P E T$ cardiopulmonary exercise testing, NACRT neoadjuvant chemoradiotherapy

International Physical Activity Questionnaires [17] and Leisure Time Physical Activity Questionnaire [16].

\section{Quality assessment}

Table 2 summarizes the quality of the included studies. The total scores for methodological quality ranged from 5 to 8 points on the 10-point PEDro scale. Four studies presented a high methodological quality $[16,23,24,36]$, and four studies presented a good methodological quality $[15,17,34,35]$.

\section{Intervention characteristics}

The main characteristics of the exercise interventions are presented in Table 3 according to the FITT principle. The frequency of a single exercise session was presented in all studies 


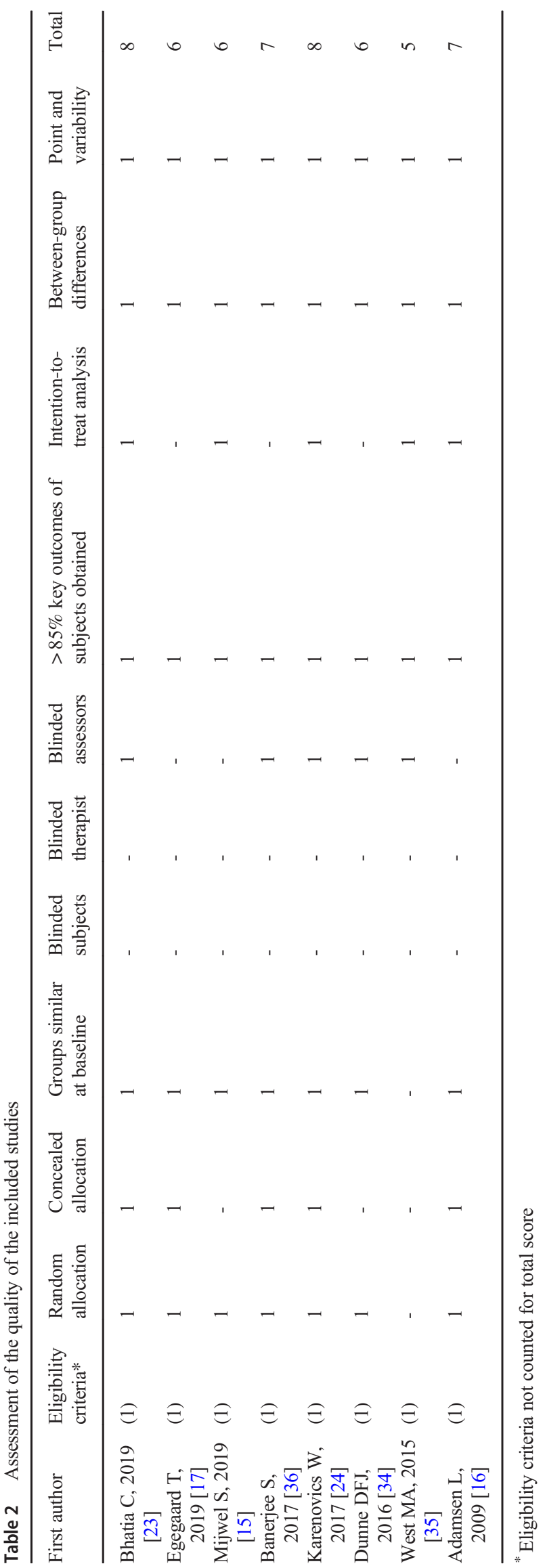

and ranged from two $[15,36]$ to five times per week [17]. Intensity prescription was reported in all studies except for one [15], whereas the specific interval configuration was accurately shown in all trials except for two [16, 34]. The duration of a single high-intensity bout lasted from $15 \mathrm{~s} \mathrm{[23,}$ 24] to $5 \mathrm{~min}$ [36]. The length of a HIIT intervention per session (without warm up and cool down phases) lasted from 11 [15] to $40 \mathrm{~min}$ [36], and the sessions were integrated into total intervention periods lasting between 2 and 3 [23] and 16 weeks [15]. The progression of exercise based on individualized intensity prescription with cardiopulmonary exercise testing (CPET) at baseline was reported in all studies. The prescribed intensity was defined as a given percentage of peak work rate [17, 23], peak oxygen consumption [34, $35]$, and peak heart rate $[16,36]$ achieved at the CPET. Furthermore, three of the eight studies used the Borg scale of perceived exertion to additionally adjust for intensity [17, $23,36]$. All interventions were supervised and executed on a cycle ergometer. Two studies performed long-term followup lasting more than 1 year $[15,24]$. The adherence of the study population was apparent in six of the eight studies [16, $17,23,24,35,36]$ and ranged from 71 [16] to $96 \%$ [35]. One study had a multimodal prehabilitative approach that included relaxation, body awareness training, and massage in the exercise training program [16]. Survival data were presented in one study, with a similar distribution of deaths reported after a 1-year follow-up in the study population [24].

Five of the eight studies reported no adverse events [17, $23,34-36]$, and one study reported three drop-outs during the cardiovascular training. One patient with a brain tumor was excluded due to a seizure episode, and two patients withdrew from the study because of leucopenia and/or increased blood pressure [16].

\section{Descriptive analyses}

The mean values and standard deviations at baseline and at the end are presented in Supp. Tables 1 and 2.

\section{Meta-analysis peak oxygen uptake $\left(\mathrm{VO}_{2}\right.$ max $)$}

Figure 2 shows an overview of the effects of the HIIT intervention compared to UC (MD 2.76, 95\% CI 1.65, 3.86). The heterogeneity test results were as follows: $\mathrm{Q}(\mathrm{df}=6)=5.45$, $p=0.4872$. Publication bias for $\mathrm{VO}_{2 \max }$ was assessed with a funnel plot graph (Supp. Figure 1).

\section{Meta-analysis peak work rate}

Figure 3 illustrates an overview of the effects of the HIIT interventions compared with UC on the peak work rate (MD $12.68,95 \%$ CI $5.80,19.56)$. The heterogeneity test results 


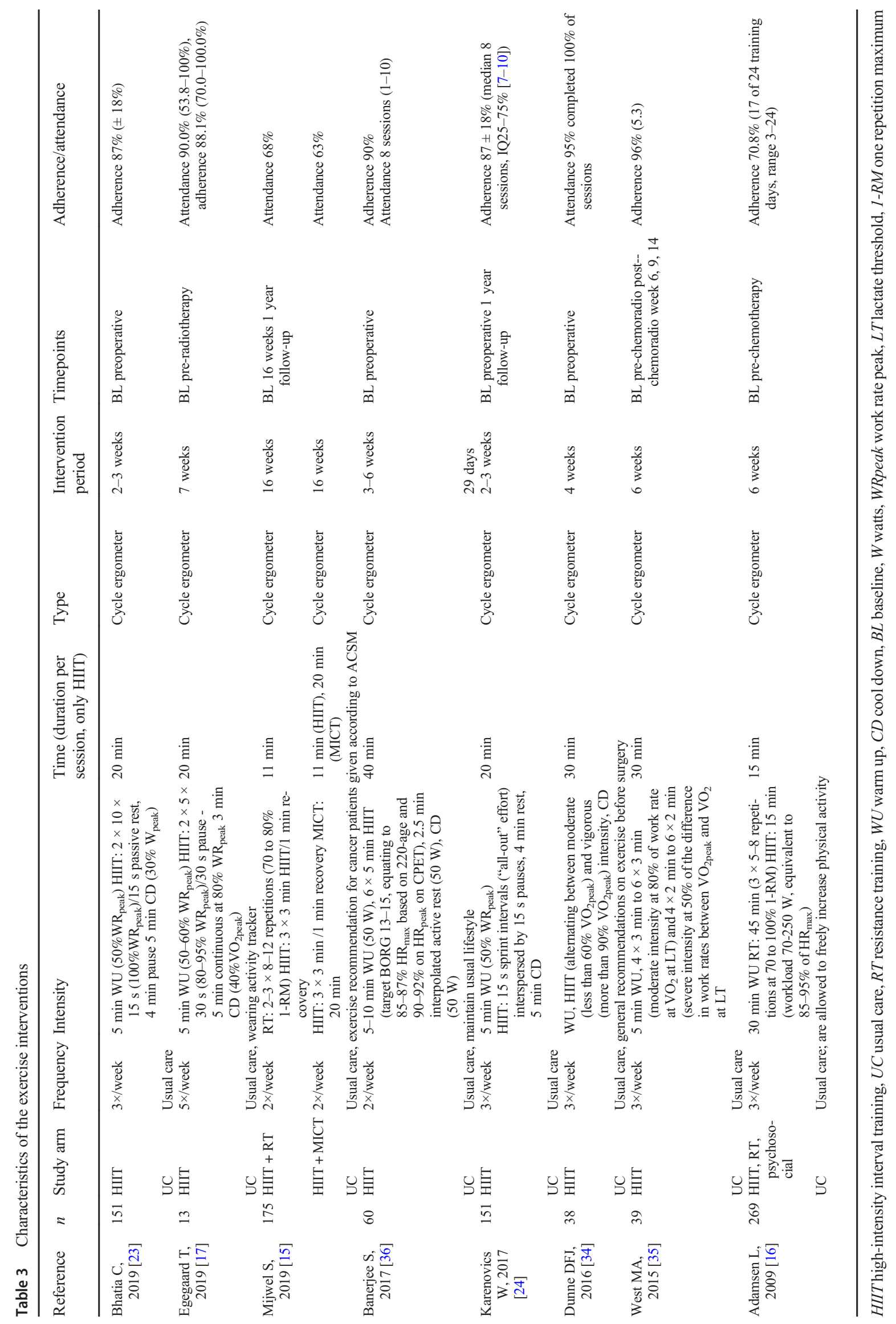


were as follows: $\mathrm{Q}(\mathrm{df}=4)=26.96, p<.0001$. Publication bias for the peak work rate is illustrated in Supp. Figure 2.

\section{Functional outcomes}

Two studies each reported functional capacity outcomes such as the 6MWT $[17,23]$, with significant improvements in one trial (median 20\%, 95\% CI 14-26\%, $p<0.001$ ) [23]; in studies testing muscle strength, gains were reported in lower limb strength (effect size 1.03), handgrip strength (effect size 0.590.71 ) [15], and an average growth of $29.6 \%$ (SD 36.4) for leg press, chest press, and pull down in the treatment arm compared with UC [16]. Pulmonary function was assessed in two studies, but no significant differences were shown between baseline and post-intervention in the two groups [17, 24].

\section{Patient-reported outcomes}

Health-related QoL was evaluated in five of the eight studies. Two studies evaluated this factor with the European Organization for Research and Treatment of Cancer questionnaire (EORTC-QLQ C30) [15, 16], two studies used the 36item short form (SF-36) [16, 34], and one study used the Functional Assessment of Cancer Therapy-Lung survey (FACT-L) [17]. One study noted significant effects on the fatigue subscale (effect size $0.33, p<0.05$ ) of the EORTCQLQ C30 [16], whereas two studies found significant effects in several subscales of the SF-36, with the results favoring the HIIT intervention [16, 34].
Over a 1-year follow-up period, one study demonstrated a significant reduction in cancer-related fatigue (effect size $0.34, p=0.012$ ), assessed by the Piper Fatigue Scale (PFS); additionally, in their assessment of return to work (RTW), they revealed that the proportion of patients on more than half-time sick leave was significantly lower in the MICT/ HIIT group compared with patients receiving UC (5.9 vs. $31 \%, p=0.006)$. The same study noted that the symptom burden measured with the Memorial Symptom Assessment Scale (MSAS) was significantly lower in both treatment arms (effect size - 0.46) after 12 months of follow-up [15].

One study assessed psychosocial parameters such as depression and anxiety indicators with the Hospital Anxiety and Depression Scale (HADS) and demonstrated no significant differences within or between groups in the study population [17].

Two of the eight studies reported on pre-interventional physical activity (PA) with self-report instruments such as the Leisure Time Activity Questionnaire [16] and the revised version of the International Physical Activity Questionnaire (IPAQ-L) [17].

\section{Additional clinical outcomes}

Activity data (steps) were tracked with an accelerometer in two studies $[17,35]$. One study showed a significant difference in the within-group comparison of the average number of steps for the exercise $(p<0.0001)$ and control groups $(p=$ 0.003 ) during the 6-week intervention. However, between-

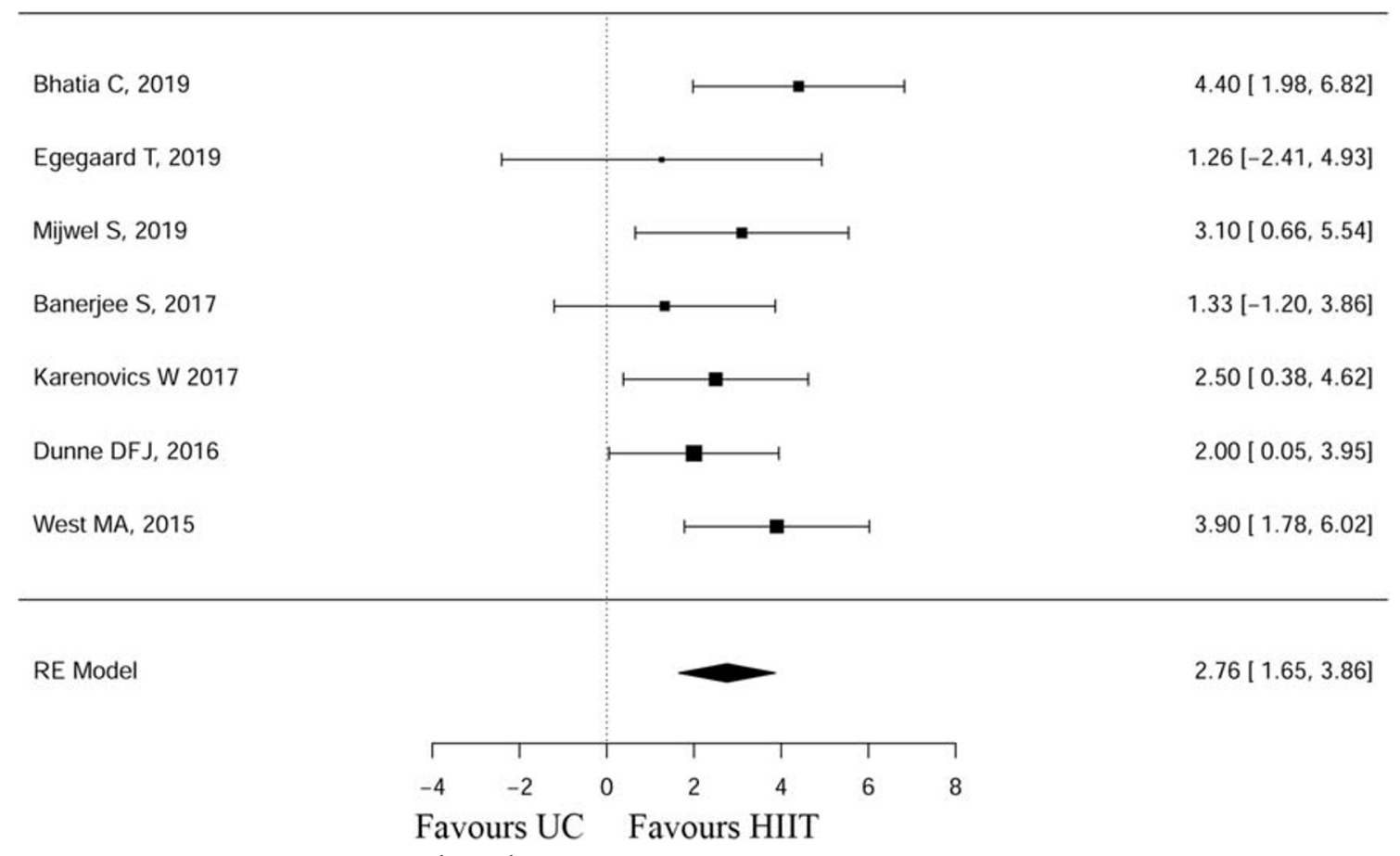

Fig. 2 Forest plot of peak oxygen uptake $\left(\mathrm{ml} \mathrm{kg}^{-1} \mathrm{~min}^{-1}\right)$ 
group differences were not significant in this study $(p=0.84)$ [35].

Tumor regression was assessed and classified in one study with magnet resonance imaging (MRI), revealing a significant clinical response to the applied neoadjuvant chemoradiotherapy in favor of the exercise intervention group $(p=0.006)$ [35].

In the five studies in which HIIT preceded cancer surgery [23, 24, 34-36], three studies reported on postoperative recovery outcomes such as length of stay in the post-anesthesia care unit/hospital and postoperative complications [24, 34, 36]. One of these studies reported a significant difference in the study groups for postoperative outcomes. Karenovic et al. demonstrated that prehabilitation led to a reduction in pulmonary complications (23\% in the HIIT group vs. $44 \%$ in the UC group, $p=0.018$ ) and a shorter stay in the post-anesthesia care unit (median $-7 \mathrm{~h}$, interquartile range, -4 to $-10 \mathrm{~h}$ ) in lung cancer patients [24].

\section{Discussion}

This systematic review and meta-analysis investigated the effects of HIIT in the prehabilitation of cancer patients. Recently, a shift from a reactive curative to a proactive preventive approach in healthcare is emerging, with a primary focus on optimization of patients' health status between diagnosis and post treatment recovery. During preoperative care, prehabilitative interventions such as exercise have been shown to accelerate recovery by mitigating potential treatment-related impairments and deconditioning [11, 13]. In that regard, HIIT emerged as an effective and timeefficient aerobic exercise modality to gain maximal aerobic capacity in a relatively short time period [23]. However, evidence about its implementation in prehabilitative settings is scarce, and reviews focusing solely on prehabilitation and HIIT are missing.

This systematic review and meta-analysis of seven included trials revealed a significant increase in aerobic capacity due to HIIT programs (reflected by $\mathrm{VO}_{2 \max }$ growth, which is a strong singular predictor of cancer-related mortality) compared with UC. This finding is consistent with a study reporting on HIIT interventions to increase $\mathrm{VO}_{2 \max }$ in the therapy and aftercare of cancer patients [31]. Furthermore, despite the heterogeneity of the study designs and their small sample sizes, the descriptive data analysis demonstrated that supervised HIIT is a feasible and safe training method for prehabilitation, with a low risk of major adverse events. Moreover, it contains some notable health benefits for patients such as a reduction of cancer-related fatigue, increased healthrelated QoL, increased muscle strength, tumor regression after neoadjuvant chemoradiotherapy, and faster RTW after cancer therapy in favor of the intervention group; no significant changes in pulmonary function were observed. However, findings on other functional and clinical outcomes were inconsistent, specifically the 6MWT and postoperative outcomes such as length of stay and postoperative complications.

From eight included studies in this meta-analysis, two considered stage IV patients with peripheral metastasis, which indicated that HIIT might be safe also for patients with an advanced disease. However, this finding is difficult to extrapolate to other cancer types and definitely needs to be proven in future studies. Generally, patients with cardiovascular contraindications for CPET, such as severe cardiopulmonary limitations, were a priori excluded in most studies. One study restricted the eligible patients with a WHO performance status of $<1$, but simultaneously included stage IIIA to IV patients [17], which implied that advanced disease does not necessarily need be accompanied by a low performance status. As most cancers usually occur in the elderly population, where comorbidities are common [38], prehabilitation offers an opportunity to additionally optimize modifiable pre-existing risk factors.

In summary, each patient has unique comorbidities and physical capabilities, and as a result, exercise needs to be individually tailored to meet each patient's specific needs, based on an adequate baseline assessment and (ideally) subsequent monitoring and professional guidance during training sessions.

As discussed earlier, a preoperative, high-intensity program of interval training within a short time frame prior to surgery is supposed to increase the patient's aerobic capacity, aiming to minimize operative stress and complications. Indeed, $\mathrm{VO}_{2 \text { peak }}$, a strong indicator of aerobic capacity, is the best independent predictor of the surgical complication rate [39]. Therefore, it appears logical to evaluate the efficacy and clinical impact of prehabilitation programs by assessing potential postoperative complications and the length of hospital stay. Three of the eight studies included in this review presented postoperative outcomes; however, only one study reported a significant reduction in (pulmonary) complications and a shorter stay in the post-anesthesia care unit [24]. To increase the relevance of HIIT interventions in prehabilitation, future research should put a stronger focus on postoperative outcomes.

A substantial number of studies reported associations between regular physical activity and all-cause mortality [40-42], thus indicating physical activity to be an independent risk factor for specific chronic diseases, including cardiovascular diseases, diabetes, and colon and breast cancer [43, 44]. However, to date, the underlying dose-response relationship remains unclear. Following international guidelines, strong evidence for the beneficial effects of exercise on healthrelated outcomes exists, including anxiety, depressive symptoms, QoL, physical function, and lymphedema. Depending on the outcome, a target intensity for aerobic exercise between 


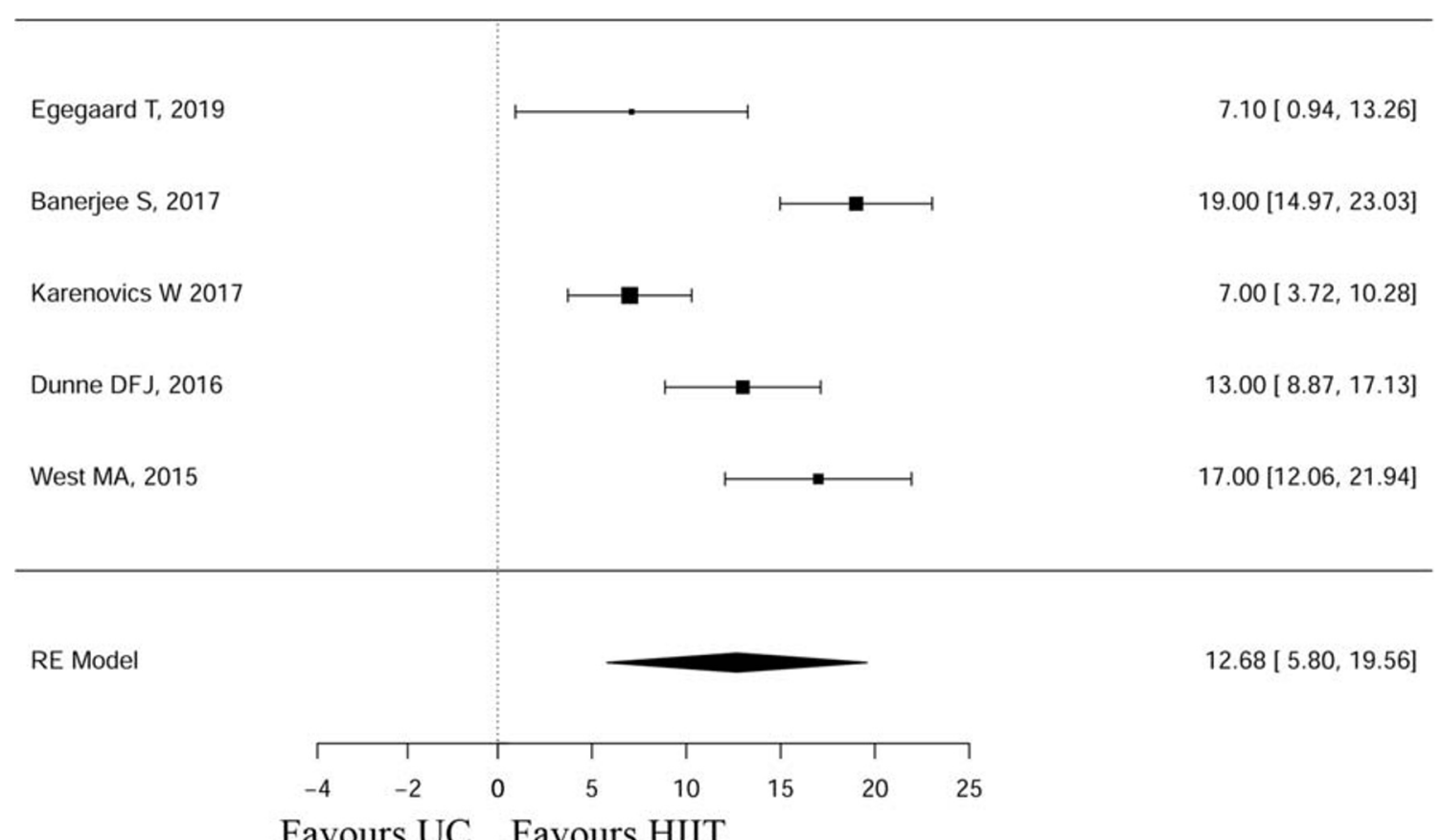

Fig. 3 Forest plot of the peak work rate (watts)

60 and $80 \%$ of maximum heart rate $\left(\mathrm{HR}_{\max }\right)$, which corresponds to 60 to $80 \%$ of $\mathrm{VO}_{2 \max }$ with a duration of 30 to $60 \mathrm{~min}$, is recommended [8]. Presuming that a one-size-fitsall approach cannot be applicable for all patients, the specification of the individualized target intensity zones varies between experts, using different models, i.e., percentages of $\mathrm{VO}_{2 \text { peak }}$, heart rate reserve/max, or work rate peak after CPET before an intervention starts $[8,45]$. In a critical analysis of these general exercise prescription recommendations, applied after completing primary therapy, breast cancer survivors tended to either be overloaded or under-challenged when using percentages of heart rate reserve or $\mathrm{VO}_{2 \text { max }}$; conversely, $\mathrm{HR}_{\text {max }}$ appeared to be adequately intense for this specific population [46]. In this context, individualized threshold concepts, i.e., blood lactate or ventilatory thresholds (as a gold standard), are considered more accurate and reflect an individualized metabolic profile [47]. The studies included in this review used a heterogeneous approach of prescribing individualized workload intensities and included $\mathrm{WR}_{\text {peak }}, \mathrm{HR}_{\text {peak }}$, and $\mathrm{VO}_{2 \text { peak }}$, without explaining how interval variables (duration, frequency, or intensity) were selected, and failed to account for differences in cardiovascular and metabolic stress. No study considered these threshold concepts in their methods, except one study which applied a mixed model with lactate threshold and $\mathrm{VO}_{2 \text { peak }}$ for vigorous intensity [35]. This might be of particular relevance for cancer patients, as a recent meta-analysis concluded that HIIT was more efficient than continuous training in patients with coronary artery disease at increasing both $\mathrm{VO}_{2 \text { peak }}$ and the anaerobic threshold $(p<0.01$ for each) [48].
Optimizing exercise-related outcomes is the present challenge in the prehabilitation of cancer patients; as over the past decades, cancer management has substantially improved, and modern therapeutic strategies in cancer are associated with higher survival rates [49]. It is often overlooked that approximately $40 \%$ of cancer survivors are $<65$ years old; hence, they are potentially of an employable age, but long-term symptoms and impairments, such as fatigue or physical weakness, might threaten cancer patients' daily life activity. RTW after sick leave is challenging, and an observed higher unemployment rate of cancer patients is often accompanied by social isolation, financial losses, and reductions in self-esteem [50, 51]. In this review, one study discussed aspects of sick leave and RTW and reported a significantly lower proportion of patients on more than half-time sick leave in the intervention group [15]. Optimizing the prehabilitation and RTW of workers with cancer is important for improving the well-being of this vulnerable group and for reducing the societal and financial impacts of cancer.

This review and meta-analysis have some limitations. Given the high degree of data variability and heterogeneity of the included studies, suitable data was only available for two outcome parameters $\left(\mathrm{VO}_{2 \text { peak }}\right.$ and work rate peak). Furthermore, the number of studies and sample sizes was low. However, no publication bias was indicated in the funnel plots. No three-arm designs (moderate continuous intensity training vs. HIIT vs. UC) were identified during the screening process; therefore, no respective comparative analysis was executable. 
These limitations highlight the present deficits in research. For a comprehensive understanding of the effects of HIIT in cancer prehabilitation, future research needs to focus on highquality comparative studies between HIIT and MICT, and encompass exercise planning via threshold concept vs. established methods, in various cancer entities, stages, and therapy regimes. Moreover, not just the effects of HIIT on performance parameters but also on postoperative complication rates, long-term survival, and socio-economic impact urgently need to be assessed. All of these puzzle pieces are required for the ultimate aim of prescribing individualized exercise recommendations for each single cancer patient.

\section{Conclusion}

HIIT is a novel and pragmatic exercise method in prehabilitation, and this meta-analysis showed that it displays significant benefits on aerobic capacity and peak power output compared with UC, despite the short intervention duration applied in some studies.

Funding Open access funding provided by Medical University of Vienna.

\section{Compliance with ethical standards}

Conflict of interest The authors declare that there is no conflict of interest.

Open Access This article is licensed under a Creative Commons Attribution 4.0 International License, which permits use, sharing, adaptation, distribution and reproduction in any medium or format, as long as you give appropriate credit to the original author(s) and the source, provide a link to the Creative Commons licence, and indicate if changes were made. The images or other third party material in this article are included in the article's Creative Commons licence, unless indicated otherwise in a credit line to the material. If material is not included in the article's Creative Commons licence and your intended use is not permitted by statutory regulation or exceeds the permitted use, you will need to obtain permission directly from the copyright holder. To view a copy of this licence, visit http://creativecommons.org/licenses/by/4.0/.

\section{References}

1. Bray F, Ferlay J, Soerjomataram I, Siegel RL, Torre LA, Jemal A (2018) Global cancer statistics 2018: GLOBOCAN estimates of incidence and mortality worldwide for 36 cancers in 185 countries. CA Cancer J Clin 68:394-424. https://doi.org/10.3322/caac.21492

2. Adami H-O, Berns A, Celis JE, Vries E, Eggermont A, Harris A, zur Hausen H, Pelicci PG, Ringborg U (2018) European academy of cancer sciences - position paper. Mol Oncol 12:1829-1837. https://doi.org/10.1002/1878-0261.12379

3. Chen Y, Li X, Ma H et al (2020) Exercise training for improving patient-reported outcomes in patients with advanced-stage cancer: a systematic review and meta-analysis. J Pain Symptom Manag 59: 734-749.e10. https://doi.org/10.1016/j.jpainsymman.2019.09.010

4. Nadler MB, Desnoyers A, Langelier DM, Amir E (2019) The effect of exercise on quality of life, fatigue, physical function, and safety in advanced solid tumor cancers: a meta-analysis of randomized control trials. J Pain Symptom Manag 58:899-908.e7. https://doi. org/10.1016/j.jpainsymman.2019.07.005

5. Keilani M, Hasenoehrl T, Baumann L, Ristl R, Schwarz M, Marhold M, Sedghi Komandj T, Crevenna R (2017) Effects of resistance exercise in prostate cancer patients: a meta-analysis. Support Care Cancer 25:2953-2968. https://doi.org/10.1007/ s00520-017-3771-z

6. Wisløff U, Nilsen TIL, Drøyvold WB, Mørkved S, Slørdahl SA, Vatten LJ (2006) A single weekly bout of exercise may reduce cardiovascular mortality: how little pain for cardiac gain? 'The HUNT study, Norway.'. Eur J Cardiovasc Prev Rehabil 13:798804. https://doi.org/10.1097/01.hjr.0000216548.84560.ac

7. O'Donovan G, Lee I-M, Hamer M, Stamatakis E (2017) Association of "weekend warrior" and other leisure time physical activity patterns with risks for all-cause, cardiovascular disease, and cancer mortality. JAMA Intern Med 177:335-342. https://doi.org/ 10.1001/jamainternmed.2016.8014

8. Campbell KL, Winters-Stone KM, Wiskemann J et al (2019) Exercise guidelines for cancer survivors: consensus statement from international multidisciplinary roundtable. Med Sci Sports Exerc 51:2375-2390. https://doi.org/10.1249/MSS.0000000000002116

9. Moore SC, Lee I-M, Weiderpass E, Campbell PT, Sampson JN, Kitahara CM, Keadle SK, Arem H, Berrington de Gonzalez A, Hartge P, Adami HO, Blair CK, Borch KB, Boyd E, Check DP, Fournier A, Freedman ND, Gunter M, Johannson M, Khaw KT, Linet MS, Orsini N, Park Y, Riboli E, Robien K, Schairer C, Sesso H, Spriggs M, van Dusen R, Wolk A, Matthews CE, Patel AV (2016) Association of leisure-time physical activity with risk of 26 types of cancer in 1.44 million adults. JAMA Intern Med 176: 816-825. https://doi.org/10.1001/jamainternmed.2016.1548

10. Silver JK, Baima J (2013) Cancer prehabilitation. Am J Phys Med Rehabil 92:715-727. https://doi.org/10.1097/PHM. 0b013e31829b4afe

11. Carli F, Scheede-Bergdahl C (2015) Prehabilitation to enhance perioperative care. Anesthesiol Clin 33:17-33. https://doi.org/10.1016/ j.anclin.2014.11.002

12. Kalogera E, Nelson G, Liu J et al (2018) Surgical technical evidence review for gynecologic surgery conducted for the Agency for Healthcare Research and Quality Safety Program for Improving Surgical Care and Recovery. Am J Obstet Gynecol 219:563.e1563.e19. https://doi.org/10.1016/j.ajog.2018.07.014

13. Nelson G, Bakkum-Gamez J, Kalogera E, Glaser G, Altman A, Meyer LA, Taylor JS, Iniesta M, Lasala J, Mena G, Scott M, Gillis C, Elias K, Wijk L, Huang J, Nygren J, Ljungqvist O, Ramirez PT, Dowdy SC (2019) Guidelines for perioperative care in gynecologic/oncology: Enhanced Recovery After Surgery (ERAS) Society recommendations - 2019 update. Int J Gynecol Cancer 29:651-668. https://doi.org/10.1136/ijgc-2019-000356

14. Ven Fong Z, Chang D, Lillemoe K, Nipp R, Tanabe K, Qadan M (2019) Contemporary opportunity for prehabilitation as part of an enhanced recovery after surgery pathway in colorectal surgery. Clin Colon Rectal Surg 32:095-101. https://doi.org/10.1055/s-00381676473

15. Mijwel S, Jervaeus A, Bolam KA, Norrbom J, Bergh J, Rundqvist H, Wengström Y (2019) High-intensity exercise during chemotherapy induces beneficial effects 12 months into breast cancer survivorship. J Cancer Surviv 13:244-256. https://doi.org/10.1007/ s11764-019-00747-z

16. Adamsen L, Quist M, Andersen C, Moller T, Herrstedt J, Kronborg D, Baadsgaard MT, Vistisen K, Midtgaard J, Christiansen B, Stage M, Kronborg MT, Rorth M (2009) Effect of a multimodal high 
intensity exercise intervention in cancer patients undergoing chemotherapy: randomised controlled trial. BMJ 339:895-898. https:// doi.org/10.1136/bmj.b3410

17. Egegaard T, Rohold J, Lillelund C, Persson G, Quist M (2019) Preradiotherapy daily exercise training in non-small cell lung cancer: a feasibility study. Rep Pract Oncol Radiother 24:375-382. https:// doi.org/10.1016/j.rpor.2019.06.003

18. Cave J, Paschalis A, Huang CY, West M, Copson E, Jack S, Grocott MPW (2018) A systematic review of the safety and efficacy of aerobic exercise during cytotoxic chemotherapy treatment. Support Care Cancer 26:3337-3351. https://doi.org/10.1007/ s00520-018-4295-x

19. Treanor C, Kyaw T, Donnelly M (2018) An international review and meta-analysis of prehabilitation compared to usual care for cancer patients. J Cancer Surviv 12:64-73. https://doi.org/10. 1007/s11764-017-0645-9

20. Karlsen T, Aamot I-L, Haykowsky M, Rognmo Ø (2017) High intensity interval training for maximizing health outcomes. Prog Cardiovasc Dis 60:67-77. https://doi.org/10.1016/j.pcad.2017.03. 006

21. Metcalfe RS, Babraj JA, Fawkner SG, Vollaard NBJ (2012) Towards the minimal amount of exercise for improving metabolic health: beneficial effects of reduced-exertion high-intensity interval training. Eur J Appl Physiol 112:2767-2775. https://doi.org/10. 1007/s00421-011-2254-Z

22. Ramos JS, Dalleck LC, Tjonna AE, Beetham KS, Coombes JS (2015) The impact of high-intensity interval training versus moderate-intensity continuous training on vascular function: a systematic review and meta-analysis. Sports Med 45:679-692. https:// doi.org/10.1007/s40279-015-0321-z

23. Bhatia C, Kayser B (2019) Preoperative high-intensity interval training is effective and safe in deconditioned patients with lung cancer: a randomized clinical trial. J Rehabil Med 51:712-718. https://doi.org/10.2340/16501977-2592

24. Karenovics W, Licker M, Ellenberger C, Christodoulou M, Diaper J, Bhatia C, Robert J, Bridevaux PO, Triponez F (2017) Short-term preoperative exercise therapy does not improve long-term outcome after lung cancer surgery: a randomized controlled study $\dagger$. Eur J Cardiothoracic Surg 52:47-54. https://doi.org/10.1093/ejcts/ ezx030

25. Brunelli A, Salati M, Refai M et al (2013) Development of a patient-centered aggregate score to predict survival after lung resection for non-small cell lung cancer. J Thorac Cardiovasc Surg 146: 385-90.e1-2. https://doi.org/10.1016/j.jtcvs.2013.04.007

26. Schmid D, Leitzmann MF (2014) Association between physical activity and mortality among breast cancer and colorectal cancer survivors: a systematic review and meta-analysis. Ann Oncol 25: 1293-1311. https://doi.org/10.1093/annonc/mdu012

27. Adams SC, DeLorey DS, Davenport MH et al (2017) Effects of high-intensity aerobic interval training on cardiovascular disease risk in testicular cancer survivors: a phase 2 randomized controlled trial. Cancer 123:4057-4065. https://doi.org/10.1002/cncr.30859

28. Thum JS, Parsons G, Whittle T, Astorino TA (2017) High-intensity interval training elicits higher enjoyment than moderate intensity continuous exercise. PLoS One 12:e0166299. https://doi.org/10. 1371/journal.pone.0166299

29. Saanijoki T, Tuominen L, Tuulari JJ, Nummenmaa L, Arponen E, Kalliokoski K, Hirvonen J (2018) Opioid release after highintensity interval training in healthy human subjects. Neuropsychopharmacology 43:246-254. https://doi.org/10.1038/ npp.2017.148

30. Drigny J, Gremeaux V, Dupuy O, Gayda M, Bherer L, Juneau M, Nigam A (2014) Effect of interval training on cognitive functioning and cerebral oxygenation in obese patients: a pilot study. J Rehabil Med 46:1050-1054. https://doi.org/10.2340/16501977-1905
31. Mugele H, Freitag N, Wilhelmi J, Yang Y, Cheng S, Bloch W, Schumann M (2019) High-intensity interval training in the therapy and aftercare of cancer patients: a systematic review with metaanalysis. J Cancer Surviv 13:205-223. https://doi.org/10.1007/ s11764-019-00743-3

32. Moher D, Liberati A, Tetzlaff J et al (2009) Preferred reporting items for systematic reviews and meta-analyses: the PRISMA statement. Ann Intern Med 151(264-9):W64. https://doi.org/10.7326/ 0003-4819-151-4-200908180-00135

33. Verhagen AP, de Vet HC, de Bie RA et al (1998) The Delphi list: a criteria list for quality assessment of randomized clinical trials for conducting systematic reviews developed by Delphi consensus. J Clin Epidemiol 51:1235-1241. https://doi.org/10.1016/s08954356(98)00131-0

34. Dunne DFJ, Jack S, Jones RP, Jones L, Lythgoe DT, Malik HZ, Poston GJ, Palmer DH, Fenwick SW (2016) Randomized clinical trial of prehabilitation before planned liver resection. Br J Surg 103: 504-512. https://doi.org/10.1002/bjs.10096

35. West MA, Loughney L, Lythgoe D, Barben CP, Sripadam R, Kemp GJ, Grocott MPW, Jack S (2015) Effect of prehabilitation on objectively measured physical fitness after neoadjuvant treatment in preoperative rectal cancer patients : a blinded interventional pilot study $\dagger$. Br J Anaesth 114:244-251. https://doi.org/10.1093/ bja/aeu318

36. Banerjee S, Manley K, Shaw B, Lewis L, Cucato G, Mills R, Rochester M, Clark A, Saxton JM (2017) Vigorous intensity aerobic interval exercise in bladder cancer patients prior to radical cystectomy: a feasibility randomised controlled trial. Support Care Cancer 26:1515-1523. https://doi.org/10.1007/s00520-0173991-2

37. Campbell KL, Neil SE, Winters-Stone KM (2012) Review of exercise studies in breast cancer survivors: attention to principles of exercise training. Br J Sports Med 46:909-916. https://doi.org/10. 1136/bjsports-2010-082719

38. Froehner M, Brausi MA, Herr HW, Muto G, Studer UE (2009) Complications following radical cystectomy for bladder cancer in the elderly. Eur Urol 56:443-454. https://doi.org/10.1016/j.eururo. 2009.05.008

39. Jones LW, Eves ND, Haykowsky M, Joy AA, Douglas PS (2008) Cardiorespiratory exercise testing in clinical oncology research: systematic review and practice recommendations. Lancet Oncol 9: 757-765. https://doi.org/10.1016/S1470-2045(08)70195-5

40. Lee D-C, Sui X, Ortega FB, Kim YS, Church TS, Winett RA, Ekelund U, Katzmarzyk PT, Blair SN (2011) Comparisons of leisure-time physical activity and cardiorespiratory fitness as predictors of all-cause mortality in men and women. Br J Sports Med 45:504-510. https://doi.org/10.1136/bjsm.2009.066209

41. Myers J, Prakash M, Froelicher V, Do D, Partington S, Atwood JE (2002) Exercise capacity and mortality among men referred for exercise testing. N Engl J Med 346:793-801. https://doi.org/10. 1056/NEJMoa011858

42. Blair SN (1995) Changes in physical fitness and all-cause mortality. A prospective study of healthy and unhealthy men. JAMA J Am Med Assoc 273:1093-1098. https://doi.org/10.1001/jama.273.14. 1093

43. Myers J, McAuley P, Lavie CJ, Despres JP, Arena R, Kokkinos P (2015) Physical activity and cardiorespiratory fitness as major markers of cardiovascular risk: their independent and interwoven importance to health status. Prog Cardiovasc Dis 57:306-314. https://doi.org/10.1016/j.pcad.2014.09.011

44. Kyu HH, Bachman VF, Alexander LT, Mumford JE, Afshin A, Estep K, Veerman JL, Delwiche K, Iannarone ML, Moyer ML, Cercy K, Vos T, Murray CJL, Forouzanfar MH (2016) Physical activity and risk of breast cancer, colon cancer, diabetes, ischemic heart disease, and ischemic stroke events: systematic review and 
dose-response meta-analysis for the Global Burden of Disease Study 2013. BMJ i3857. https://doi.org/10.1136/bmj.i3857

45. Garber CE, Blissmer B, Deschenes MR, Franklin BA, Lamonte MJ, Lee IM, Nieman DC, Swain DP, American College of Sports Medicine (2011) Quantity and quality of exercise for developing and maintaining cardiorespiratory, musculoskeletal, and neuromotor fitness in apparently healthy adults. Med Sci Sports Exerc 43:1334-1359. https://doi.org/10.1249/MSS. 0b013e318213fefb

46. Scharhag-Rosenberger F, Kuehl R, Klassen O, Schommer K, Schmidt ME, Ulrich CM, Wiskemann J, Steindorf K (2015) Exercise training intensity prescription in breast cancer survivors: validity of current practice and specific recommendations. J Cancer Surviv 9:612-619. https://doi.org/10.1007/s11764-015-0437-z

47. Meyer T, Lucía A, Earnest CP, Kindermann W (2005) A conceptual framework for performance diagnosis and training prescription from submaximal gas exchange parameters - theory and application. Int J Sports Med 26:S38-S48. https://doi.org/10.1055/s-2004830514

48. Elliott AD, Rajopadhyaya K, Bentley DJ, Beltrame JF, Aromataris EC (2015) Interval training versus continuous exercise in patients with coronary artery disease: a meta-analysis. Heart Lung Circ 24: 149-157. https://doi.org/10.1016/j.hlc.2014.09.001

49. Ferlay J, Colombet M, Soerjomataram I, Dyba T, Randi G, Bettio M, Gavin A, Visser O, Bray F (2018) Cancer incidence and mortality patterns in Europe: estimates for 40 countries and 25 major cancers in 2018. Eur J Cancer 103:356-387. https://doi.org/10. 1016/j.ejca.2018.07.005

50. de Boer AGEM, Taskila T, Ojajärvi A, van Dijk FJH, Verbeek JHAM (2009) Cancer survivors and unemployment. JAMA 301: 753-762. https://doi.org/10.1001/jama.2009.187

51. Wells M, Williams B, Firnigl D, Lang H, Coyle J, Kroll T, MacGillivray S (2013) Supporting 'work-related goals' rather than 'return to work' after cancer? A systematic review and metasynthesis of 25 qualitative studies. Psychooncology 22:12081219. https://doi.org/10.1002/pon.3148

Publisher's note Springer Nature remains neutral with regard to jurisdictional claims in published maps and institutional affiliations. 